\title{
POLA KONSUMSI MEDIA DAN KAITANNYA DENGAN PARTISIPASI MASYARAKAT PADA ISU-ISU PUBLIK DI KOTA PADANG
}

\author{
Yayuk Lestari' ${ }^{1}$, Vitania Yulia ${ }^{2}$, Yesi Puspita ${ }^{3}$ \\ Jurusan Ilmu Komunikasi, Universitas Andalas \\ Kampus Unand Limau Manis, Padang, Sumatera Barat, 25163, Indonesia \\ No Telp./HP: (0751) 71266/ ${ }^{1089624404395,{ }^{2}+4917620139089,{ }^{3} 081373553661}$ \\ E-mail: 1'estari.yayuk11@yahoo.com, ${ }^{2}$ vyulia@yahoo.com, ${ }^{3}$ yesiranza@gmail.com
}

Naskah diterima tanggal 20 April 2017, direvisi tanggal 8 Agustus 2017, disetujui tanggal 2017

\section{MEDIA CONSUMPTION PATTERNS AND CONNECTION TO THE CIVIC PARTICIPATION IN PUBLIC ISSUES IN PADANG}

\begin{abstract}
The low participation of Padang citizens in the local elections leads to questions on how effective is the media's role in providing proper information about local political issues for the people. How media is able to attract attention and motivation of the people to actively involve in public Concerns. Through the media, the people can be connected to public concerns, gain, build, and spread their opinion or discourses which are considered important for the civic life and prosperity. This research is aimed at analyzing the correlation between behavior of media consumption with the civic engagement and public participation. The method applied in this research is quantitative correlation approach. The samples are collected by using questionnaires. The location was decided by using random sampling techniques from which four village districts were selected as research locations. The samples were gathered from 100 respondents based on Taro Yamame's formulated with $10 \%$ critical values. The age factor becomes dominant in media choice. Younger respondents tend to access online media instead of the conventional one, while the other respondents tend to choose the conventional media. Online media give room or chances to the Respondents to actively participate in the society. On the other hand, the conventional media have not yet able to provide a stimulus or allow for the people to actively involve in democracy. Test result indicated there are correlations found between the online media consumers with the civic engagement and public participation.
\end{abstract}

Keywords: public concerns, media consumption, civic participation, media role, Padang City.

\begin{abstract}
Abstrak. Rendahnya partisipasi masyarakat Kota Padang untuk menentukan pemimpinnya pada pemilihan kepala daerah memunculkan pertanyaan tentang bagaimana individu sebagai pengguna media mampu termediasi secara proporsional dengan isu-isu publik. Bagaimana media sendiri mampu memunculkan atensi dan motivasi untuk masyarakat agar terlibat aktif dalam isu-isu publik. Melalui media, masyarakat bisa terhubung dengan isu-isu publik (public concerns), memperoleh, membangun, sekaligus menyebarkan wacana atau opini yang dianggap penting bagi kehidupan dan kesejahteraan masyarakat. Penelitian ini bertujuan menganalisis hubungan perilaku individu mengonsumsi media (media consumption) dengan keterlibatan individu terhadap isu-isu publik, baik yang bersifat orientasi maupun partisipasi (civic engagement dan public participation). Metode penelitian yang digunakan adalah pendekatan kuantitatif correlational research. Teknik pengambilan sampel dengan menggunakan kuesioner. Pemilihan lokasi dilakukan dengan teknik simple random sampling dan didapatkan empat kelurahan yang menjadi sample. Jumlah responden 100 orang yang didasarkan dengan rumus Taro Yamane dengan nilai kritis sebesar $10 \%$. Faktor usia menjadi faktor dominan pada pilihan media. Kaum muda lebih memilih mengakses media online dibandingkan media konvensional, sebaliknya semakin tua usia
\end{abstract}


responden maka lebih memilih media konvensional. Media online memberikan ruang atau kesempatan kepada responden untuk berpartisipasi aktif di masyarakat sebaliknya media konvensional belum memberikan rangsangan dan juga wadah untuk masyarakat dalam berdemokrasi. Dari uji korelasi yang sudah dilakukan terlihat ada hubungan antara pengguna media online dengan partisipasi terhadap isu-isu publik. Sebaliknya pengguna media konvensional lebih mengetahui isu-isu di sekitar tempat tinggalnya namun belum melakukan tindakan apapun jika terjadi sebuah masalah.

Kata kunci: isu-isu publik, konsumsi media, partisipasi masyarakat, peran media, Kota Padang.

\section{PENDAHULUAN}

Ide awal dari demokrasi adalah bagaimana masyarakat turut berperan serta dalam pembangunan, karenanya dibuatlah instrumen untuk menjaring keterlibatan masyarakat. Salah satu alat yang digunakan untuk melibatkan masyarakat adalah pemilihan umum dan pilkada di tingkat daerah. Namun tentunya partisipasi masyarakat dalam demokrasi tidak hanya berhenti ketika memasuki bilik suara. Idealnya masyarakat terus berpartisipasi dengan cara mendapatkan infomasi, menyampaikan pendapat, dan melakukan pengawasan yang berkaitan dengan isu publik. Pada tahap inilah kehadiran media sebagai pilar keempat demokrasi menjadi penting. Media bukan hanya sebagai medium untuk mengantarkan informasi dan mendidik masyarakat namun juga menstimulus masyarakat untuk terus berpartisipasi di dunia demokrasi.

Media masih memiliki peran yang mampu memengaruhi opini masyarakat yang menggunakannya. Namun, media yang idealnya objektif sayangnya memiliki sifat ambivalen, khususnya media konvensional. Hal ini disebabkan karena posisi media sebagai institusi yang hampir tidak mungkin indipendent atau bebas terhadap berbagai kepentingan. Apalagi dengan landskap/struktur media massa di Indonesia yang bersifat konglomerasi dan koorperasi (Nugroho, Putri \& Laksmi, 2013), di mana media digerakkan layaknya perusahaan yang berorientasi laba dan bersifat komersiil. Media cenderung memoduksi program atau pemberitaan yang memiliki nilai jual dan menghasilkan kapital. Akibatnya banyak ditemui program-program yang tidak edukatif dan yang hanya mengedepankan aspek hiburan saja. Alih-alih berorientasi kepada kemaslahatan masyarakat, media khususnya televisi lebih berorientasi kepada rating dengan menempatkan program acara seperti sinetron dan reality TV di jam-jam utama siaran (prime-time). Sementara program hard news, talk show, dan dokumentari yang sifatnya lebih menggambarkan kondisi nyata masyarakat, hanya memiliki porsi kecil dalam pemrograman dengan alasan rating yang rendah dan tidak populer di masyarakat.

Kondisi ini diperburuk ketika stasiun televisi cenderung melakukan duplikasi content, apabila salah satu program pada stasiun tertentu terbukti memiliki rating tinggi, maka stasiun TV yang lain ramai-ramai membuat program serupa, contohnya tayangan infotainment yang hampir seluruh stasiun memiliki dan menayangkannya dengan porsi jam tayang yang cukup besar. Masyarakat akhirnya lebih sering mendiskusikan hal-hal privat dalam ruang publik seperti isu-isu pernikahan, perceraian, dan gosip para selebriti.

Sementara dalam hal pemberitaan (news programming), yang seharusnya menjadi ruang bagi pemirsa untuk mengetahui informasi aktual, saat ini pemberitaan justru mengarah kepada sensasionalitas demi mendongkrak rating. Akibatnya masyarakat tidak mampu membedakan antara fakta dan fiksi sebagaimana pemberitaan atau program yang mengarah kepada infotainment daripada berita aktual. Sebagai contoh bisa diamati bagaimana media massa di Indonesia melaporkan berita tentang bencana alam. Misalnya ketika tsunami terjadi di Aceh, bagian yang menjadi fokus pemberitaan adalah korban-korban bencana alam. Sementara ketika bencana serupa juga terjadi di Jepang, media massa di sana justru tidak 
mengeksploitasi korban, namun mereka menyampaikan isu-isu yang sifatnya menggugah masyarakat untuk bangkit dan berjuang mengatasi bencana alam.

Kondisi di atas menggambarkan batasan antara isu publik dan privat dalam ruang publik (public sphere) semakin kabur dan saling tumpang tindih. Sementara itu informasi yang disampaikan oleh media semakin sulit dibedakan antara yang faktual atau hanya fiksi. Akibatnya masyarakat semakin teralienasi dan terasing dari kehidupan dan permasalahan riil yang sedang mereka hadapi. Pada saat yang bersamaan angka partisipasi masyarakat terhadap isu-isu publik mengalami kemunduran. Cara yang paling mudah untuk mengetahui bagaimana berkurangnya partisipasi masyarakat dalam berdemokrasi adalah dengan melihat semakin tingginya angka golongan putih. Pada konteks di Sumatera Barat khususnya di Kota Padang angka pemilih yang abstain pada Pemilihan Gubernur 2015 mencapai angka tertinggi se Sumatera Barat yakni mencapai $47,38 \%$ (Harian Haluan, 2015), sedangkan pada Pemilihan Walikota Padang pada putaran kedua tahun 2014 angka abstain 46,4\% (Faruqi, 2014). Fenomena tersebut tidak hanya terjadi di Kota Padang, namun terjadi hampir di seluruh Indonesia. Bahkan di negara maju lainnya seperti Inggris dan Amerika Serikat trend seperti ini sudah lama memunculkan kekhawatiran. Semakin menurunnya partisipasi masyarakat tentu saja memuculkan pertanyaan bagaimana peran media untuk mendorong masyarakat berpartisipasi dalam pembangunan.

Fenomena enggannya masyarakat terlibat aktif dalam bertindak atau hanya sekedar mencari informasi juga terlihat pada pilkada, salah satunya Pilkada Provinsi Sumatera Barat. Pada tanggal 9 Desember 2015 telah diadakan pilkada serentak. Pada tanggal tersebut penduduk Sumatera Barat juga memilih calon gubernurnya. Ada dua calon pasangan yang menjadi kandidat gubernur yakni, calon incumbent Irwan Prayitno dan Nasrul Abit dengan lawannya yakni Musliar Kasim dan Fauzi Bahar. Namun, belum banyak masyarakat yang mengetahui akan diadakannya pilkada serentak dan siapa saja yang menjadi kontestannya. Ketidaktahuan ini bukan hanya karena minimnya informasi dan publikasi, namun juga dikarenakan ketidakpedulian masyarakat terhadap pilkada serentak ini. Bagi mereka tidak ada perubahan apapun yang akan terjadi dengan adanya pemilihan gubernur ini. Tidak adanya insiatif untuk mencari informasi tentang pilihan dan informasi politik menjadi pertanyaan apa penyebabnya, bagaimana cara menumbuhkan kesadaran keterlibatan isu-isu publik sehingga masyarakat Indonesia terutama di Kota Padang bisa menjadi bagian dari civic society.

Kehadiran media baru seperti internet membuat cara masyarakat mengonsumsi media mengalami perubahan, terutama di kota besar dan di kalangan anak muda. Penggunaan internet di Indonesia mengalami kenaikan signifikan ketika smartphone mulai diperkenalkan. Dengan adanya smartphone maka pengguna bisa mengakses internet di mana saja. Sebelum diperkenalkan smartphone, kebanyakan masyarakat Indonesia mengakses internet lewat warung internet, kini kehadiran warung internet sudah jarang ditemukan dan diganti dengan penyediaan game online.

Berdasarkan latar belakang di atas, maka permasalahan yang diangkat dalam penelitian ini adalah bagaimana interaksi antara individu sebagai pengguna media mampu termediasi isu-isu publik yang akhirnya memunculkan atensi dan motivasi untuk terlibat aktif dalam isu-isu tersebut? Untuk menjawab pertanyaan tersebut maka peneliti melibatkan seluruh pengguna media baik media elektronik, maupun media cetak dan juga internet (new media). Dengan asumsi perkembangan teknologi yang pesat memungkinkan penggunanya untuk mengonsumsi berbagai macam varian media, namun media mana yang lebih dominan dalam menytimulus keterlibatan masyarakat dan kaitannya dengan isu-isu publik?. Tujuan penelitian ini adalah untuk menganalisis hubungan perilaku individu mengonsumsi media (media consumption) dengan keterlibatan individu terhadap isu-isu publik baik yang bersifat orientasi maupun partisipasi (civic engagement dan public participation). 


\section{LANDASAN KONSEP}

\section{Pola Penggunaan Media (Media Consumption Pattern)}

Putnam (2000) dalam penelitiannya mengemukakan bahwa konsumsi menonton televisi adalah penyebab paling dominan dari menurunnya level social capital dan public participation. Menurutnya televisi memprivatisasi waktu senggang manusia, televisi juga memprivatisasi aktivitas dan interaksi dengan orang lain. Di waktu senggang seseorang akan lebih banyak membicarakan masalah pribadi yang dibawa ke ranah publik. Putnam melihat garis batas antara publik dan privat dikaburkan oleh media.

Persoalan yang seharusnya di ranah privat menjadi ranah publik lewat kooptasi media. Pemikiran Putnam sejalan dengan Bennett \& Segerberg (2012) yang melihat media engagement sebagai hasil dari media consumption. Bennett \& Segerberg (2012) kemudian mendefinisikan media engagement sebagai kombinasi dari kognitif, motivasi, kebiasaan, dan perilaku yang normatif di mana hal ini konsisten dengan konten media dan konsumsi media oleh masyarakat (user) pada kehidupan sehari- harinya.

Pada bagian akhir dari buku Jenkins (2006) Cultural Convergence dinyatakan bahwa pengguna media akan memiliki kekuatan yang luar biasa dalam budaya media konvergen jika mereka mengenal dan menggunakan kekuatan dan haknya sebagai konsumen dan warga negara (consumer citizen) untuk berpartisipasi dalam budaya demokrasi.

Dalam bukunya, Jenkins mengusung tema perubahan budaya (cultural shift) berdasarkan interaksi antara media konvergen, budaya partisipasi, dan kecerdasan kolektif. Kecerdasan kolektif ini memiliki asumsi bahwa tidak satupun makhluk di dunia yang mengetahui semuanya secara baik, yang ada hanyalah individu yang mengenal dan mengetahui serba sedikit, yang apabila dikumpulkan (melalui diskusi dan tukar pendapat) akan membentuk suatu kecerdasan kolektif.
Melalui inovasi media terciptanya media-media baru seperti social network sites (SNS) dalam bentuk Facebook,Twitter, dan lain-lain yang memungkinkan masyarakat membagi informasi, berdiskusi, berdebat secara rasional untuk membahas masalahmasalah yang ada (Negroponte, 1995). Kecerdasan kolektif akan membawa masyarakat menuju keputusan yang baik dalam menyelesaikan suatu permasalahan. Konsep ini tentunya sangat cocok diterapkan bagi masyarakat Indonesia yang memiliki tradisi sosial yang tinggi, bersifat kekerabatan, dan sering terlibat dalam berbagai kelompok sosial seperti kelompok pengajian, arisan, dan sebagainya.

Sejalan dengan asumsi ini, dalam serangkaian studi yang dilakukan oleh Dahlgren (2006, 2009, 2012) yang membangun konsep tentang civic culture (budaya publik), yaitu konsep bagaimana orang-orang membangun dan melihat dirinya sebagai insan atau potensial partisan yang memiliki kemampuan untuk melibatkan dirinya dalam permasalahan sosial. Menurut Dahlgren, budaya politik beroperasi secara maksimal melalui media, contohnya keterikatan dengan berita-berita aktual di media dapat dilihat sebagai bagian dari civil society. Tindakan dan keinginan untuk selalu mengikuti (keep up) dengan isu-isu yang ada di masyarakat dapat dipandang sebagai elemen atau ciri kewarganegaraan. Aktivitas oleh non jurnalis yang menggunakan platform seperti Facebook, Twitter, Blog , dan Youtube untuk mendistribusikan materi jurnalistik yang menjadikan informasi yang penting semakin beragam, interaktif, partisan, dan cepat tersebar di masyarakat. Dahlgren memercayai bahwa urusan politis adalah sesuatu yang seharusnya terjadi dan dilakukan di tengahtengah masyarakat dan bukan di luar masyarakat (oleh sekelompok elite tertentu).

\section{Partisipasi Publik}

Menurut Dahlgren (2006) terbentuknya public participation berawal dari keterikatan individu secara mendalam terhadap suatu objek yang menghasilkan atensi yang terus menerus sehingga akhirnya memunculkan tindakan. 
Tindakan ini kemudian disebut sebagai civic/public participation. Partisipasi publik dapat dibedakan atas dua definisi, yakni secara konvensional dan non konvensional. Dalam konteks masyarakat demokrasi partisipasi publik dalam bentuk konvensional dapat dilihat dari pemilihan umum, maka salah satu bentuk partisipasi publiknya adalah menggunakan suaranya dalam pemilihan. Selain itu bisa juga berupa keterlibatan sebagai anggota partai politik, ikut menandatangani suatu petisi, melakukan demonstrasi ataupun menjadi anggota LSM, dan sebagainya. Sedangkan dalam konteks partisipasi non konvensional, perasaan bertanggungjawab sebagai warga negara yang berhubungan dengan selain urusan politik, seperti tindakan mengonsumsi barang-barang yang ramah lingkungan, boikot terhadap bentuk konsumerisasi, melakukan daur ulang (recycling), menjadi bagian dalam kegiatan pergerakan hijau (greenpeace), menandatangani atau menyebarkan email petisi dan mengadvokasi suatu kegiatan protes, dan sebagainya.

Partisipasi konvensioanal lebih bersifat sporadic dan individual. Sedangkan dalam konteks konvesional, partisipasi publik bersifat kolektif, rutin, dan terorganisir.

Perbedaan makna dari kedua jenis partisipasi publik ini sangat berguna dalam penelitian ini, supaya tidak terjebak dalam asumsi yang sederhana dalam melihat kaitan antara meningkatnya jumlah golput di Indonesia dengan menurunnya partisipasi publik secara umum.

Dalam hal ini, jika partisipasi publik secara konvensional menurun bukan berarti partisipasi publik dalam pengertian konvensional juga menurun, demikian juga sebaliknya. Seperti yang diuraikan di atas bahwa persyaratan dari terwujudnya public participation berakar dari dari public engagement. Public engagement dalam terminologi Dahlgren (2006) memiliki makna yang paralel dengan public connection dalam studi yang dilakukan oleh Couldry, Livingstone \& Markham (2007).

\section{METODE PENELITIAN}

Penelitian yang dilakukan menggunakan pendekatan kuantitatif yang diikuti dengan pendekatan kualitatif, data kualitatif digunakan untuk menguraikan fakta-fakta dan fenomena-fenomena yang menujukkan bentuk civi caction. Pengumpulan data kualitatif berupa wawancara dengan komunitas seribu Guru Sumatera Barat dilakukan setelah pengumpulan data kuantitatif, untuk menjelaskan bentuk civic action yang dilakukan masyarakat di Kota Padang, civic action ini muncul sebagai hasil persinggungan dengan adanya internet (dalam konteks ini Instagram dan Twitter).

Pendekatan kuantitatif yang digunakan adalah desain penelitian survei yang bersifat correlational research, yakni melihat hubungan antara dua variabel atau lebih. Uji korelasi yang digunakan adalah korelasi Pearson Product Moment.Teknik analisis data adalah suatu metode yang digunakan untuk mengolah hasil penelitian guna memperoleh suatu simpulan. Dengan melihat kerangka pemikiran teoretis, maka teknik analisis data yang digunakan dalam penelitian ini adalah metode sequential explanatory research, yaitu pengumpulan data dan analisis data kuantitatif pada tahap pertama, dan diikuti pengumpulan data dan analisis kualitatif pada tahap kedua, guna memperkuat hasil penelitian kuantitatif yang dilakukan pada tahap pertama (Creswell, 2011). Analisis kuantitatif ini menggunakan skala pengukuran yaitu data ordinal yang ditransformasi ke data interval karena pengolahan data menggunakan Pearson Product Moment.

Untuk analisis data pengukuran menggunakan Statistical Package for Social Studies (SPSS). Data entry dan penghitungan hasil survei dilakukan dengan program SPSS 22.0.

Korelasi Rank Spearman digunakan untuk menganalisis hubungan antarvariabel independen pola konsumsi media (X) dengan variabel dependen partisipasi publik(Y). Penjelasan dibagi menjadi 4 (empat) tahapan, yaitu: 1) Persiapan data (tabulasi data); 2) Transformasi data; 3) Uji korelasi;4) Intepretasi data. Pada pendekatan kuantitatif 
teknik pengumpulan data primer yang digunakan adalah kuesioner menggunakan skala likert, sedangkan data sekunder didapatkan dengan teknik wawancara. Data kuantitatif didukung dengan analisis deskriptif dan inferensial.

Berdasarkan data BPS Kota Padang (2016), penduduk Kota Padang berjumlah 902.413 orang. Namun populasi Kota Padang tidak bisa dijadikan acuan untuk penentuan responden karena jumlah penduduk tidak mencerminkan jumlah pengguna media. Karenanya penentuan responden untuk populasi yang belum diketahui, maka digunakanlah rumus Taro Yamane dan kemudian didapatkan angka 100 responden.

Penyebaran kuesioner dilakukan di empat kelurahan yang telah dipilih dengan teknik simple random sampling, yakni Kelurahan Lapai (Kecamatan Nanggalo), Kelurahan Jati (Kecamatan Padang Timur), Kelurahan Ujung Gurun (Kecamatan Padang Barat), dan Kelurahan Parupuk Tabing (Kecamatan Koto Tangah). Satu kelurahan diambil sample sebanyak 25 orang responden sehingga didapatkan secara keseluruhan 100 orang responden dengan nilai kritis sebesar $10 \%$.

\section{HASIL PENELITIAN DAN PEMBAHASAN}

\section{Karakteristik Responden}

Berdasarkan hasil kuesioner dari 100 orang responden ada $54 \%$ orang responden yang berusia di bawah 34 tahun. Pada kelompok yang berusia di bawah 34 tahun ditemukan angka $37 \%$ orang yang menjadikan media online sebagai media yang paling sering dikonsumsi di luar televisi, radio, dan media cetak. Menurut survei yang dilakukan APJII (2012) pada kategori usia ini yang disebut dengan digital native, yakni generasi mengadopsi teknologi secara cepat tanpa harus diajarkan berbeda dengan kelompok di atas 34 tahun, yang disebut digital immigrant. Responden di kelompok ini sebagian adalah mahasiswa, fresh graduate, dan pekerja baru. Kelompok digital immigrant memerlukan waktu lebih lama untuk mengadopsi sebuah teknologi baru. Responden di kelompok ini sudah mempunyai kehidupan yang lebih mapan dan mempunyai keluarga.

Ada 88 orang yang berasal dari suku Minangkabau, dan sisanya berasal dari suku Jawa, Batak, Melayu, dan Tionghoa. Suku Minangkabau adalah suku mayoritas di Kota Padang. Suku Minangkabau banyak yang merantau ke luar Sumatera Barat namun sebaliknya di Kota Padang walaupun merupakan ibu kota Sumatera Barat kehidupannya cenderung homogen, hanya sedikit dari penduduk Kota Padang yang bukan berasal dari suku Minangkabau. Karenanya faktor latar belakang budaya dan agama pada penelitian ini tidak memberikan faktor signifikan jika dibandingkan dengan usia, pendapatan, dan latar belakang pekerjaan.

\section{Media Habits}

Walaupun pamornya mulai meredup, responden masih menjadikan televisi sebagai media favorit $(50 \%)$, terutama di kalangan kelompok di atas 34 tahun, selanjutnya media online diminati $40 \%$ dari responden.Temuan ini sejalan dengan apa yang ditemukan oleh Rauch (2006) bahwa hanya 10\% responden yang berusia 18-34 tahun yang secara rutin menonton televisi. Sementara pada responden dengan kategori usia 35 tahun ke atas lebih memprioritaskan informasi melalui media televisi. Media konvensional lainnya seperti radio dan koran juga mulai ditinggalkan oleh responden, hanya kelompok digital immigrant yakni kelompok dengan usia di atas 34 tahun yang masih membaca koran.

Selain faktor usia alokasi waktu penggunaan media akan berbeda juga, bergantung dari pekerjaan yang dilakukan oleh responden. Ibu rumah tangga menghabiskan empat sampai lima jam waktunya untuk menonton televisi sedangkan responden dengan pekerjaan lainnya mengalokasikan waktu sekitar dua sampai tiga jam untuk menonton televisi. Hal ini dimungkinkan karena ibu rumah tangga memiliki banyak waktu luang di rumah, sehingga memiliki waktu lebih besar untuk menonton televisi. Mayoritas responden memilih televisi sebagai sarana mencari hiburan, karakteristik televisi 
dengan kemampuan audio dan visual menjadikan media pelepas lelah setelah beraktivitas seharian.

Responden menganggap televisi dan media online sebagai media yang paling efektif dan efisien. Dari $40 \%$ pengguna media online lebih dari $40 \%$ responden menghabiskan lebih dari empat jam waktunya per hari di dunia maya. Semakin tingginya penetrasi internet, semakin ditinggalkannya media konvensional. Walaupun belum ada data pasti berapa pengguna internet di Sumatera Barat, namun dari data APJII menunjukkan angka penetrasi internet di Sumatera Barat mencapai atau 1,8 juta pengguna (APJII, 2012). Data tersebut naik dari tahun sebelumnya yang hanya $24,41 \%$ atau 1.294.171 orang. Untuk Kota Padang sendiri angka penetrasinya mencapai $24,4 \%$ atau hampir sama dengan angka penetrasi internet di Sumatera Barat, dengan jumlah pengguna sebanyak 223.000.

Wawancara kualitatif yang dilakukan menemukan bahwa responden pada umumnya menggunakan media baik itu media televisi, media cetak, maupun internet sebagai pilihan ketika tidak ada kegiatan apa-apa. Biasanya pada saat menggunakan media terutama televisi, responden mencari-cari informasi di program berita atau hanya sekedar mencari hiburan di berbagai program yang ditampilkan stasiun televisi.

Setiap responden memiliki waktu yang berbeda-beda dalam mengonsumsi media, begitupun berlaku dalam menggunakan media atau program yang mereka ikuti. Responden lebih banyak menggunakan media TV dengan tema atau topik yang berbeda-beda sesuai dengan keinginan. Mereka tertarik melihat TV karena program yang ditampilkan, bagi responden bukan medianya yang mereka lihat, tapi lebih ke program apa yang mereka tampilkan.

Dalam mengonsumsi media, responden tidak terlalu mengikuti perkembangan topiktopik tertentu, mereka hanya sekedar tahu saja dan tidak terlibat terlalu jauh dalam mengikuti sebuah isu. Dalam mencari informasi di media TV responden biasanya menonton TV One atau Metro TV, tetapi mereka tidak terlalu percaya apa yang disampaikan oleh media, karena mereka sudah mulai sadar bahwa informasi yang disampaikan oleh media ada yang dimanipulasi atau dalam konteks politik memihak pada kelompok tertentu, tetapi berbeda dengan kasus kriminalitas, responden lebih memercayai informasi tersebut. Salah satu faktor yang membuat berkurangnya kepercayaan masyarakat terhadap media yakni ketika Pemilihan Presiden 2014. Pada saat itu responden menilai media terlihat berpihak kepada calon presiden sesuai dengan kepentingan pemilik media. Contohnya responden tidak begitu tertarik dengan isu-isu politik yang disampaikan beberapa stasiun TV yang hampir setiap hari, mereka hanya mengikuti dan tidak ingin terlibat jauh dalam isu politik.

Tabel 1, memperlihatkan perbedaan umur memengaruhi pemilihan media pada media online, yakni semakin muda usia maka akses ke media online akan semakin sering. Sebaliknya, semakin tua usia responden maka semakin jarang untuk mengakses media online. Dari uji penggunaan media yang peneliti lakukan, hanya media online yang memiliki hubungan dengan usia dan memiliki tingkat korelasi rendah, sedangkan media lain seperti radio, koran, dan televisi tidak memiliki hubungan. Data ini juga menegaskan temuan dari APJII (2012) bahwa memang ada hubungan antara usia dan penggunaan media online.

Tabel 1

Interpretasi hubungan antara karakteristik individu (usia) dengan media habits

\begin{tabular}{ccl}
\hline \multicolumn{2}{c}{ Nilai Koefisien Korelasi } & \multicolumn{1}{c}{ Keterangan } \\
\cline { 1 - 2 } Media habits & Usia & $\begin{array}{l}\text { Terdapat hubungan dengan tingkat korelasi sedang } \\
\text { dan berlawanan arah }\end{array}$ \\
\hline Alokasi akses media online & -0.561 &
\end{tabular}

Sumber: Data Primer Peneliti (2016) 


\section{Public Participation}

Studi tentang apakah penggunaan teknologi mampu atau berpotensi mendorong masyarakat berpartisipasi ke isu-isu publik dan sekaligus menjadikan berdemokrasi lebih baik sudah banyak dilakukan, di antaranya Castells (2008), Kahn \& Kellner (2005), Shirky (2011), Lim (2013), dan Nugroho, Nugraha, Laksmi, et al. (2013). Kehadiran media dalam partisipasi publik diperlukan untuk menyampaikan informasi, menghubungkan masyarakat dan pemerintah untuk membicarakan isu-isu publik. Peran media terhadap pembentukan wacana yang membentuk ruang publik (public sphere) di masyarakat tentunya sangat penting. Berbagai argumentasi, baik yang optimis maupun yang pesimis, menyoroti bagaimana media bagaikan pisau bermata dua, memiliki potensi untuk menjadikan masyarakat demokratik yang sensitif terhadap masalah publik atau sebaliknya membuat menjauhkan masyarakat permasalahan-permasalahan riil (Nugroho, Nugraha, Laksmi, et al., 2013). Idealnya, melalui media masyarakat bisa memperoleh, membangun sekaligus menyebarkan wacana atau opini yang dianggap penting bagi kehidupan dan kesejahteraan masyarakat. Media secara tidak langsung telah menghubungkan masyarakat dengan isu-isu publik (public concerns) tanpa dibatasi jarak dan waktu. Keterlibatan individu akan isu-isu publik biasanya dimulai dari kegiatan mendapatkan informasi melalui media dan membicarakan atau mendiskusikannya dengan orang lain baik dalam ruang nyata (tatap muka) maupun dalam ruang virtual (melalui media sosial). Kegiatan ini akan membentuk ruang publik (public sphere) yang akhirnya mendorong keinginan seseorang baik secara individu maupun kolektif untuk mengetahui lebih dalam, terlibat/berorientasi dan bertindak lebih jauh terhadap isu tersebut.

Isu-isu publik seperti isu politik kurang menjadi pilihan, isu sosial dan kriminalitas lebih menjadi pilihan untuk dikonsumsi. Sebuah studi yang dilakukan oleh Cohen \& Kahne (2011) mencoba menemukan solusi untuk menstimulus generasi muda supaya menunjukkan ketertarikannya kepada politik dan isu-isu publik. Hasil studi tersebut membuktikan bahwa internet, khususnya media sosial merupakan alat yang efektif untuk menstimulus generasi muda (usia 15-25 tahun) untuk berpartisipasi dalam politik. Mereka menemukan bahwa $45 \%$ dari generasi muda yang terlibat dalam studi ini menjadi tertarik pada berita politik tertentu setelah mereka melihat berita tersebut diposting di Facebook atau Twitter.Temuan serupa juga ditemukan pada penelitian ini, di mana masyarakat lebih menyukai informasi tentang hiburan dibandingkan dengan isu-isu publik seperti politik, ekonomi, dan kesehatan.

Keterkaitan karakteristik responden pada konteks usia dengan keterlibatannya terhadap isu-isu publik terlihat pada Tabel 2, di mana terdapat korelasi antara usia dan keterlibatannya untuk terlibat aktif lewat organisasi.

Data ini juga menunjukkan bahwa kaum muda memiliki kepedulian yang lebih tinggi dengan isu publik dibandingkan dengan responden yang berusia lebih tua. Hal serupa juga bisa dilihat di media online, di mana banyak anak muda yang terlibat dengan isu-isu publik di sosial media. Kehadiran media sosial bukan hanya memberikan informasi namun juga memberikan wadah bagi kalangan muda untuk berpartisipasi langsung.

Tabel 2

Interpretasi Karakteristik Individu (usia) dengan civic action

\begin{tabular}{|c|c|c|}
\hline \multicolumn{2}{|c|}{ Nilai Koefisien Korelasi } & \multirow{2}{*}{ Keterangan } \\
\hline Civic action & Usia & \\
\hline Pernah ikut berorganisasi & -0.331 & $\begin{array}{l}\text { Terdapat hubungan dengan tingkat korelasi rendah } \\
\text { dan berlawanan arah }\end{array}$ \\
\hline $\begin{array}{l}\text { Pengetahuan tentang } \\
\text { isu/masalah di lingkungan } \\
\text { sekitar tempat tinggal }\end{array}$ & 0.304 & $\begin{array}{l}\text { Terdapat hubungan dengan tingkat korelasi rendah } \\
\text { dan searah }\end{array}$ \\
\hline
\end{tabular}

Sumber: Data Primer Peneliti (2016) 
Tabel 3

Interpretasi media habits dengan civic action

\begin{tabular}{lcc}
\hline \multirow{2}{*}{ Civic action } & \multicolumn{2}{c}{ Nilai Koefisien Korelasi } \\
\cline { 2 - 3 } & \multicolumn{2}{c}{ Media habits } \\
\cline { 2 - 3 } & $\begin{array}{l}\text { Alokasi waktu } \\
\text { menonton TV }\end{array}$ & Akses media lokal \\
\hline Pengetahuan tentang isu/masalah di & 0.144 & 0.309 \\
lingkungan sekitar tempat tinggal & 0.278 & 0.32 \\
Sosialisasi di kehidupan tempat tinggal & \multicolumn{2}{c}{} \\
\hline
\end{tabular}

Sumber: Data Primer Peneliti (2016)

Tabel 2, menunjukkan ada korelasi antara jenjang usia dengan kecenderungan untuk berpartisipasi di masyarakat. Pada saat bersamaan data sebelumnya juga menunjukkan adanya kecenderungan anak muda menggunakan media online dibandingkan media konvensional. Namun pada Tabel 3 terlihat, bahwa pengguna televisi yang notabene banyak berasal dari kalangan usia lanjut ternyata memiliki angka korelasi lebih tinggi untuk lebih mengetahui isu-isu di lingkungan mereka. Jika dilihat dari karakteristik responden yang $44 \%$ berstatus istri di dalam rumah tangga, maka bisa terlihat bahwa ibu-ibu biasanya memiliki informasi lebih tentang lingkungan mereka. Namun, informasi lebih atau lebih sering bersosialisasi tidak diringi dengan kemampuan problem solving atau keinginan untuk memecahkan masalah. Ada 33\% responden yang tidak tahu harus berbuat apa jika mengetahui masalah yang terjadi di lingkungan mereka dan 25\% lebih memilih menyerahkan kepada ketua RT. Responden hanya sebatas tahu informasi namun tidak ingin terlibat lebih dalam ke masalah tersebut.

Data tersebut bisa dijelaskan bahwa konsumsi media televisi menurut Putnam (2000) dalam penelitiannya menemukan bahwa menonton televisi adalah penyebab paling dominan dari menurunnya level social capital dan public participation. Menurutnya televisi memprivatisasi waktu senggang seseorang, televisi juga memprivatisasi aktivitas dan interaksi dengan orang lain. Pada konteks media konvensional sulit untuk mengatur content media pilihan masyarakat. Di waktu senggang masyarakat lebih banyak membicarakan masalah pribadi yang dibawa ke ranah publik, Putnam melihat garis batas antara publik dan privat dikaburkan oleh media. Persoalan yang seharusnya di ranah privat menjadi ranah publik lewat kooptasi media. Televisi memberikan masyarakat informasi namun tidak memberikan solusi atau inspirasi untuk menyelesaikan masalah di masyarakat. Sebaliknya kehadiran media online memprivatisasi waktu senggang masyarakat, namun dengan banyaknya pilihan isu membuat masyarakat bisa mendapatkan pilihan informasi lebih beragam. Hal ini juga membuat ketika seseorang ingin mendapatkan informasi yang sesuai dengan ketertarikannya, dia bisa mendapatkan informasi tersebut di internet lebih beragam. Hal tersebut mungkin tidak bisa diakomodir oleh media konvensional. Dorongan untuk berbuat sesuatu juga ditunjukkan oleh salah satunya Komunitas Seribu Guru Sumbar.

Komunitas ini berawal dari kegelisahan atas kondisi dunia pendidikan terutama di daerah yang sulit aksesnya. Pada akhirnya keprihatinan ini bisa dijadikan sebuah gerakan nyata dengan melakukan pengajaran di daerah yang susah untuk dijangkau. Untuk menyebarkan kegiatan dan visi misinya, kelompok ini menggunakan media online seperti Twitter dan Instagram. Rocky sebagai admin media sosial Komunitas Seribu Guru Sumbar mengatakan bahwa kehadiran media online selain membantu untuk menyadarkan anak muda tentang kondisi sekitar juga memberikan wadah bagi mereka dalam berkegiatan. Satu sisi yang lain media konvensional belum memberikan ruang yang siginifikan untuk masyarakat terlibat aktif, baik dari segi informasi ataupun kemampuan media sebagai ruang diskusi dan berorganisasi. Sebaliknya kehadiran media online memungkinkan penggunanya untuk berinteraksi langsung satu sama lain dan melakukan koordinasi. Kehadiran anak-anak 
muda terlibat pada isu-isu publik sayangnya tidak diikuti dengan keiginan mereka terlibat di isu politik. Mereka lebih cenderung atau bahkan bisa dikatakan menghindari isu politik. Hal ini juga terlihat pada Komunitas Seribu Guru Sumbar yang berusaha menghindari konten politik dalam postingannya di media. Bahkan seribu guru juga tidak melakukan tindakan atau pendekatan kepada pemerintah, hal ini memang disengaja karena kehadiran seribu guru pada dasarnya ingin "menyentil" pemerintah dan mengisi kesenjangan pendidikan di daerah terpencil. Bennett \& Segerberg (2012), Fuchs (2014), Castells (2008), dan Gerbaudo (2012) menjelaskan bahwa media sosial memungkinkan masyarakat untuk membangun dan memobilisasi diri dan bahkan menolak sistem yang berkuasa selama ini.

Di lain pihak keengganan untuk terlibat dalam isu politik juga terlihat dari ketidaktahuan masyarakat tentang perwakilan mereka di DPRD Kota Padang, ada 61\% responden yang tidak bisa menyebutkan salah satu nama anggota DPRD Kota Padang. Namun hal yang menarik adalah bahwa faktanya angka golput pada pilkada baik itu Pilkada Kota Padang atau pilkada pemilihan gubernur, responden pada penelitian ini hampir 90\% mengaku ikut berpartisipasi. Jika dikaitkan dengan karakteristik responden bahwa ada $30 \%$ responden yang berpendapatan $\mathrm{di}$ atas $\mathrm{Rp} 3.500 .00$ dan selanjutnya $22 \%$ responden berpendapatan antara Rp2.500.000-3.500.000 maka pemilih yang memilih abstain berasal dari kalangan menengah ke bawah. Begitu juga jika dilihat dari jenjang pendidikan maka didapatkan data serupa, yakni pada penelitian ini ada $30 \%$ responden yang berpendidikan sarjana dan $25 \%$ responden adalah mahasiswa. Data tersebut secara tidak langsung menunjukkan bahwa kalangan berpendidikan dan menengah ke atas lah yang memiliki tingkat partisipasi lebih baik. Keadaan seperti ini bisa dikaitkan dengan kondisi Kota Padang sendiri dimana banyak permasalahan yang menyangkut kepentingan kalangan masyarakat bawah yang belum bisa diselesaikan oleh pemerintah seperti misalnya kasus relokasi Pasar Raya, yang sejak tahun 2010 hingga sekarang belum juga menemukan titik temunya. Masalah yang lain yakni tingginya angka pencari kerja di Kota Padang yang mencapai 50.000 orang, angka ini mengalami kenaikan signifikan sejak 2015 (Irawan, 2016). Juga persoalan lainnya yakni ketiadaan terminal dan premanisme. Isuisu tersebut berdampak langsung terutama ke masyarakat menengah ke bawah. Berlarutlarutnya persoalan tersebut memicu adanya apatisme atas kehadiran pemerintah sehingga menyebabkan keengganan masyarakat untuk terlibat dalam pesta demokrasi.

\section{PENUTUP}

\section{Simpulan}

Implikasi dari penelitian ini terlihat bahwa perkembangan teknologi komunikasi terutama internet menjadikan pola konsumsi media masyarakat berubah. Jika dulu televisi menjadi media dominan namun kini kehadirannya mulai disaingi oleh internet. Lewat uji korelasional yang sudah dilakukan memperlihatkan perbedaan umur memengaruhi pemilihan media online. Semakin muda usia responden maka responden lebih memilih menggunakan media online dibandingkan media konvensional. Dengan menggunakan media online pengguna media online lebih leluasa untuk berkumpul, menyuarakan pendapat dan melakukan sesuatu untuk mengatasi masalah. Sedangkan pengguna media konvensional walaupun memiliki angka korelasi tinggi untuk mengetahui isu-isu bersama di lingkungan tempat tinggal mereka namun keadaan tersebut tidak diiringi dengan kemampuan mereka untuk memecahkan masalah. Hanya sebatas tahu dan membicarakan namun tidak tahu harus berbuat apa atau lebih memilih menyerahkan masalah tersebut kepada pihak berwenang.

Karakteristik media online yang memungkinkan penggunanya untuk berbagi, berdiskusi, dan melakukan tindakan nyata menjadi salah satu stimulus penggunaannya untuk membicarakan dan memecahkan masalah. Sebaliknya karakteristik media konvesional yang satu arah dan delayed feed back tidak memberikan ruang bagi 
penggunanya untuk saling bertemu mendiskusikan isu-isu publik. Content media konvensional yang dikonsumsi oleh sebagian responden lebih banyak bermuatan hiburan, selain itu content berita hanya menginformasikan namun belum memberikan stimulus untuk terlibat lebih jauh memecahkan masalah.

Dengan adanya media online isu-isu publik tidak menjadi ranah privat (pembicaraan pribadi) namun dibicarakan kemudian dicari solusi dari masalah tersebut. Salah satu isu-isu publik yang mendapat perhatiaan pengguna media online yakni isu pendidikan. Namun isu-isu politik terutama politik lokal tidak mendapat perhatian baik dari pengguna media online atau media konvensional.

\section{Saran}

Dibandingkan dengan media
konvensional, media online lebih memungkinkan sebagai penghubung interaksi masyarakat, media konvensional bersifat memberikan informasi namun tidak memberikan solusi atas permasalahan. Pemilihan media dan content yang tepat juga diimbangi dengan segmentasi audience harus dilakukan pemerintah sebagai upaya strategi komunikasi dengan masyarakat. Potensi partisipasi publik di media online harus diperhatikan oleh pemerintah yakni dengan cara terlibat aktif di media sosial dan web. Pemerintah bisa hadir dengan aktif di media sosial.

Media sosial dan web bukan hanya bersifat seremonial namun harus mampu menjadi ruang publik masyarakat. Selama ini ada kecenderungan media sosial lebih sering digunakan untuk publikasi kegiatan kepala daerah, padahal masyarakat membutuhkan informasi misalnya tentang kependudukan, pengurusan izin dan alokasi APBD. Dengan aktifnya pemerintah di media sosial dan didukung dengan content yang sesuai dengan kebutuhan masyarakat, maka pengguna media bisa berkumpul di media sosial pemerintah dan saling berinteraksi untuk membicarakan isuisu publik.

\section{DAFTAR PUSTAKA}

APJII (2012) Profil Internet Indonesia 2012. [Online]. 2012. Available from: https://apjii.or.id/downfile/file/PROFILPEN GGUNAINTERNETINDONESIA2012

[Accessed: 2 May 2016].

Bennett, W.L. \& Segerberg, A. (2012) THE LOGIC OF CONNECTIVE ACTION. Information, Communication \& Society. [Online] 15 (5), 739-768. Available from: doi:10.1080/1369118X.2012.670661.

BPS Kota Padang (2016) Jumlah Penduduk per Kecamatan Tahun 2016. [Online]. 2016. Available from: https://padangkota.bps.go.id/dynamictable/2 017/05/24/16/jumlah-penduduk-perkecamatan-tahun-2016.html.

Castells, M. (2008) The New Public Sphere: Global Civil Society, Communication Networks, and Global Governance. The ANNALS of the American Academy of Political and Social Science. [Online] 616 (1), 78-93. Available from: doi:10.1177/0002716207311877.

Cohen, C.J. \& Kahne, J. (2011) Participatory Politics. New Media and Youth Political Action. [Online]. Available from: http://ictlogy.net/bibliography/reports/projec ts.php?idp=2180.

Couldry, N., Livingstone, S. \& Markham, T. (2007) Media and Public Spheres. Richard Butsch (ed.). [Online]. London, Palgrave Macmillan UK. Available from: doi:10.1057/9780230206359.

Creswell, J.W. (2011) Controversies in Mixed Methods Research. In: Norman K. Denzin \& Yvonna S. Lincoln (eds.). Handbook of Qualitative Research. 4th edition. Thousand Oaks, CA, Sage. pp. 269-284.

Dahlgren, P. (2006) Doing citizenship. European Journal of Cultural Studies. [Online] 9 (3), 267-286. Available from: doi:10.1177/1367549406066073.

Dahlgren, P. (2009) Media and political engagement. Cambridge, University Press Cambridge.

Dahlgren, P. (2012) Reinventing Participation: Civic Agency and the Web Environment. Geopolitics, History, and International Relations. 4 (2), 27-45.

Faruqi, A. El (2014) Pasangan Inkumben Menangi Pilkada Kota Padang. [Online]. 2014. Available from: https://m.tempo.co/read/news/2014/03/12/05 8561665/pasangan-inkumben-menangi- 
pilkada-kota-padang [Accessed: 3 August 2016].

Fuchs, C. (2014) Book Review: Manuel Castells, Networks of Outrage and Hope: Social Movements in the Internet Age CastellsManuel, Networks of Outrage and Hope: Social Movements in the Internet Age. Cambridge and Malden, MA: Polity Press, 2012. Media, Culture \& Society. [Online] 36 (1), 122-124. Available from: doi:10.1177/0163443713511886.

Gerbaudo, P. (2012) Tweets and the Streets: Social Media and Contemporary Activism. Pluto Press.

Harian Haluan (2015) Golput Menang di Pilkada Serentak. [Online]. 2015. Available from: http://harianhaluan.com/news/detail/45721/g olput-menang-di-pilkada-serentak. [Accessed: 3 May 2016].

Irawan, H. (2016) Pengangguran Meningkat di Padang. [Online]. 2016. Available from: http://www.koran.padek.co/read/detail/7327 2. [Accessed: 3 February 2017].

Jenkins, H. (2006) Convergence Culture: Where Old and New Media Collide. New York, NYU Press.

Kahn, R. \& Kellner, D. (2005) Oppositional Politics and the Internet: a Critical/ Reconstructive Approach. Cultural Politics: an International Journal. [Online] 1 (1), 75100. Available from: doi:10.2752/174321905778054926.

Lim, M. (2013) Many Clicks but Little Sticks: Social Media Activism in Indonesia. Journal of Contemporary Asia. [Online] 43 (4), 636657. Available from: doi:10.1080/00472336.2013.769386.

Negroponte, N. (1995) Being Digital. Random House.

Nugroho, Y., Nugraha, L.K., Laksmi, S., Amalia, M., et al. (2013) Media and the vulnerable in Indonesia: Accounts from the margins. [Online]. Available from: http://cipg.or.id/media-and-the-vulnerablein-indonesia-accounts-from-the-margins/.

Nugroho, Y., Putri, D.A. \& Laksmi, S. (2013) Mapping the landscape of the media industry in contemporary Indonesia. [Online]. Available from: http://cipg.or.id/report-onmapping-media-industry-in-indonesia/.

Putnam, R. (2000) Bowling Alone. New York, Simon \& Schuster.

Rauch, J. (2006) All the News That's Fit to Sell: How the Market Transforms Information Into News. Journal of Communication Inquiry. [Online] 30 (3), 273-275. Available from: doi:10.1177/0196859906287770.

Shirky, C. (2011) The Political Power of Social Media: Technology, the Public Sphere, and Political Change. Foreign Affaris. [Online] 90 (1), 28-41. Available from: http://www.jstor.org/stable/25800379

[Accessed: 17 September 2016]. 